\title{
Rabbi Avraham Yizhak HaCohen Kook: Between Exile and Messianic Redemption*
}

\author{
Judith Winther
}

Copenhagen

Religious Zionism-Between Messsianism and A-Messianism

Until the 19th century and, to a certain extent, somewhat into the 20th, most adherents of traditional, orthodox Judaism were reluctant about, or indifferent towards, the active, realistic Messianism of Maimonides who averred that only the servitude of the Jews to foreign kings separates this world from the world to come. ${ }^{1}$ More broadly speaking, to Maimonides the Messianic age is the time when the Jewish people will liberate itself from its oppressors to obtain national and political freedom and independence. Maimonides thus rejects those Jewish approaches according to which the Messianic age will be a time of supernatural qualities and apocalyptic events, an end to human history as we know it.

Traditional, orthodox insistence on Messianism as a passive phenomenon is related to the rabbinic teaching in which any attempt to leave the Diaspora and return to Zion in order to establish a Jewish homeland is a transgression of the oath imposed by God on the Jewish people not to hasten the advent of the Messiah, and not to rebel against the Gentiles. Only God would be able to bring redemption, which would take the form of divine ordinance. ${ }^{2}$

It follows that important sections of Jewry opposed the budding Zionist idea. Zionism was an abomination in that it would substi- tute a purely human form of redemption for a redeemer sent by God, and therefore appeared to incite rebellion against God.

Maimonides' active, realistic Messianism was, with subsequent Zionist doctrines, first reintroduced by Judah Alkalai, Sephardic Rabbi of Semlin, Bessarabia (1798-1878), ${ }^{3}$ and Zwi Hirsch Kalisher, Rabbi of Thorn, district of Poznan (1795-1874). ${ }^{4}$

Both men taught that the Messianic process should be subdivided into a natural and a miraculous phase. Redemption is primarily in human hands, and redemption through a miracle can only come at a later stage. They held that the resettling and restoration of the land was athalta di-geullah, the beginning of redemption. They also maintained that there follows, from a religious point of view, an obligation for the Jews to return to Zion and rebuild the country by modern methods. Resettlement in modern terms provides the link necessary for the completion of the redemptive process by subsequent divine intervention. The rabbinic concept of redemption was thus extended to mean "redemption of the country" besides "redemption of the people".

As Alkalai says, "Redemption must come slowly. The land must be restored and prepared by degrees." The introduction by Alkalai 
and Kalisher of a natural, voluntaristic factor into the yearnings for redemption was a daring move for their period. ${ }^{5}$

In religious Zionism of the second generation, that of Rabbi Mordecai Eliasberg (18171889), Rabbi Shmuel Mohilewer (1824-1898), Yehiel Michael Pines (1843-1913), and Rabbi Yizhak Reines (1839-1915) Messianic elements were suppressed. Nor was much expression given to Messianic argument by later Mizrahi thinkers or during the years preceding the foundation of Ha-Po'el Ha-Mizrahi in $1922 .^{6}$

It must be pointed out, however, that the religious Zionists of this period have made a great effort to tone down the historical fact that Zionism was basically a secular movement. They defined the significance of the resettlement in Erez Israel solely in terms of Jewish religious law, knowing that a certain degree of purity can only exist in the Land of the Jews. Behind their professed attitudes, however, considerably abstract ideas were hiding. They saw the settling in Erez Israel literally as a mizvah, a religious commandment and task, since the mizvot could be fulfilled in their essential purity and perfection only in Erez Israel. They imagined that even those who join in the rebuilding of Erez Israel for secular reasons would finally achieve fulfilment of all commandments. And they felt that national consciousness is the first phase in the collective return to Torah. ${ }^{7}$ But by and large, religious Zionists still seemed unable to grasp the historical significance of the Zionist revolution. Religious Zionism became an integral part of the World Zionist Organisation but did not play a central part in the ideological moulding of the Zionist revolution during the Yishuv, the pre-1948 settlement in Palestine. It lacked the courage and the ability to confront the secular Zionist movement, which in turn rejected and denied the intrinsically religious foundations of Jewish nationhood. It also lacked a spiritual leader of distinction. One important and unusual exception was Rabbi Avraham Yizhak HaCohen Kook, a great talmudic scholar, mystic, philosopher, and poet, and a prophetic thinker. ${ }^{8}$

\section{Messianic Tension}

Rabbi Kook's teaching was an innovative interpretation of Zionism, not in terms of halakha, Jewish Law, but in terms of the Jewish religion as a belief system. He tried to understand the secular Zionist world view, attempted to see redemption as a multi-step process, visualized the Land of Israel as a spiritual centre, and imbued its centrality, although profanely based, with religious significance.

Rabbi Kook's doctrine is anchored in the Messianic feelings that were deeply ingrained in him. He was living, so to speak, in a state of Messianic tension and in the belief that the processes affecting contemporary society generally, and the Jewish people specifically, such as the return to Erez Israel and the restoration of the country, are signs of athalta digeullah, the beginning of divine redemption, figuratively speaking, the footsteps of the Messiah. The war of 1914-18 with its horrors and atrocities, reminiscent of the apocalyptic revelations associated with the End of Days, and the Balfour Declaration of 1917, which he welcomed as an act of divine deliverance, strengthened Kook's conviction that his time would reach beyond the historic hour. In the Jewish process of redemption he saw far-reaching consequences, not only for the Jewish people and for Judaism but for the world at large, which in his interpretation was undergoing constant change.

His passionate love of the Jewish people was without limits. This love was the source as well as the content of his life. Without this love of Israel, he felt, his life would have been without sense or meaning.

Listen to me, my people, out of my soul I speak to you, out of the soul of my soul, out of the string with which my life is bound to you all, and through which you are bound to me, out of the feeling which I cherish more than all my profoundest emotions: you, only you, only all, all of you, all your souls, all your generations, only you are the fullness of my life, in you I live, in you, in your 
community my life is worthy of the word life, without you I have nothing; all hopes, all endeavours, the value of life, all that I only find within myself when I am with you, and I must bind myself to the souls of you all, I must love you with a love that knows no limits-you give me fullness-for life, for work, for Torah, for prayer, for poetry, for hope. Through the channels of your being ${ }^{9} I$ feel all, I love all. On the wings of your spirit of tenderness I am borne towards love of God... by your eternity I live eternally, by your glory I am filled with splendour and magnificence, through your suffering I am filled with pain; if sorrow reigns in your hearts I am filled with affliction, with the wisdom and understanding within you I am full of wisdom and understanding (Orot $\mathrm{Ha}$ $R e^{\prime}$ ayah, p. 66-67).

As Ben Zion Bokser puts it, however,

His love reached out to all people, regardless of nationality, race or religion. This love was for him at the heart of Judaism and its highest goal was to sensitize Jews to that love, so that through them this sensitivity might also touch the rest of mankind. ${ }^{10}$

\section{Life}

Rabbi Kook was born in 1865 , in Greiva (now Griva), Latvia. He studied at several East European yeshivot among them the famous intellectual yeshivah of Volozhin. In 1888 he became rabbi of Zoimel and in 1895 rabbi of Boisk (or Bauska), Lithuania. He was invited to serve as rabbi of the Jewish community of Jaffa, then the centre of Zionist activity, and arrived in the country in 1904. During the years that he served as rabbi of Jaffa and its surroundings, newly established settlements, Kook became acquainted with the halakhic problems involved in the restoration of the country, with those mizvot, religious blessings and commandments, which are intimately and inexorably connected with life in Erez Israel. He was also keenly aware of the fact that the new yishuv, the post1881 settlement, was essentially secular and that the influence on yishuvic ways of life by the second wave of immigrants, who were socialist and anti-religious in a doctrinaire way, was every day becoming more powerful. Immediately before the outbreak of World War I in 1914, Kook travelled to Berlin in order to attend the second convention of World Agudat Israel, the movement dedicated to the preservation of Orthodoxy (their first convention was in 1912). After having spent the years between 1914 and 1918 in Switzerland and England, he, upon the emergence of the Balfour Declaration organised Degel Yerushalayim, The Banner of Jerusalem, for the "purpose of imbuing the Jewish national revival in Erez Israel with the religious ideals and traditions of the Jewish people". ${ }^{11}$ He did not return to Palestine until 1919 when he was elected chief rabbi of the entire yishuv of Palestine, an office he held until his death in 1935 .

\section{Kook's Time, His Sources, His Writings}

Rabbi Kook only to some extent, and reticently, mentions his sources in Jewish thought and among Gentile philosophers, with whom he was chiefly acquainted through secondary sources. But it is abundantly clear that Jewish medieval thinking, the teachings of Kabbalah and of Hasidism predominate in his thought. He uses traditional Hebrew formulas with a well-defined theological core; and Kabbalistic concepts, mostly Lurianic ones, are widely and comprehensibly in evidence, but this does not in itself prove their significance in his thinking as a whole. ${ }^{12}$ The spiritual and factual events of the time, its concrete, political and cultural processes, influenced his thinking and led him towards a very personal interpretation of $\mathrm{Ju}$ daism in keeping with the developmental tendencies of the 19th century. Rabbi Kook's basically positive feelings about the world, life, and people are founded in the classical sources of Judaism. Of particular importance for his thinking was the view according to which man 
is an influential factor in the world. But the eruptive optimism of Kook's teaching is far from typical of most Jewish thinkers. He appears to have indirectly adopted ideas out of the evolutionary theories of Darwin or, more precisely, from Pierre Teilhard de Chardin, the French Jesuit theologian who under Darwin's and Bergson's influence developed the theory that the world is moving towards universal, divine goodness. In the section on "The Elevation of the World" we read that

The doctrine of evolution which is steadily gaining acceptance in the world has greater affinity with the cosmic secrets of Kabbalah than has any other philosophy. (Orot $\mathrm{Ha}$ Kodesh Vol. 2, ch. 19, 537)

In speaking of the spiritual realm, rabbi Kook was axiomatically unshaken in his belief in the world's progression towards goodness and perfection. The views prevalent in contemporary philosophy and science, in which the world is presented as progression, and life as development, in Kook's thought becomes a necessary and inescapable process. It is a process of innovation and of steady elevation towards the realisation of universal goodness in which humanity is called to raise everything-itself and all of creation-towards the inconceivable and infinite source of being:

In the past, the character and the will of humankind were more savage than they are now. Expanded social connections and the distribution of scientific knowledge much refined the spirit of human beings so that even though its purification has not yet reached its final goal then their essential reason and inner volition are now able to aspire towards absolute goodness, the goodness of God. (Orot Ha-Kodesh, Vol. 2, ch. 22, 545)

The gist of rabbi Kook's thought is poetic. His writing is associative, impressionistic. His favourite concepts and terms often operate on different levels, a literal-realistic one and a metaphysical one. Fairly simple statements can have both a topical, sociological and a cosmological-supraphysical reference. ${ }^{13}$
His various writings form anything but a homogeneous, consistent theoretical system. The two books of his which are generally considered the most important, and have also been widely read, Orot Ha-Tshuvah and Orot $H a$ Kodesh, were not finished by himself but are compilations of notes written in the course of many years, edited by others, and printed several years after he wrote them.

The books that were printed in his lifetime occasionally met with great opposition by Orthodox extremist circles, to whom his words spelt heresy. In 1920, for example, after his pamphlet Orot appeared, Orthodox zealots thus condemned it (in a lampoon called $\mathrm{Kol}$ Ha-Shofar):

It must be determined whether his books are books of sorcery, and whether to forbid their publication since his fooolishness and nonsense cannot be trusted..."14

From the time that he published his long essay, "The Mission of Israel and its Nationhood" (1901) he was engaged, throughout the rest of his life, in formulating and interpreting the importance of Jewish revival in Erez Israel within a universally common, historical framework, and in shaping, in a religious context, his doctrine of the cosmic significance of the rebirth of the Jewish people.

\section{Jewish Nationalism, its Inner and Outer Shape}

Kook attempted to read a comprehensive, religious significance into Zionism, opposing the type of secular Zionists whose vision was the creation of a new society in agreement with materialist sentiments devoid of religious elements, and equally opposing Orthodox Extremist faction that in Zionism saw an inherent wish to inherit the Jewish religion-replacing it, so to speak, and in conflict also with those Zionists who made a distinction between "natural" and "religious" nationalism: ${ }^{15}$ "The spirit of God and the spirit of the people of Israel" (Orot, "Orot Ha-Thiyah" ch. 9, 64) are two 
faces of one and the same coin, one being unable to exist without the other. The Jewish people is different from other peoples in that its religion is the essence of its nationhood and the root of its existence in the world: "In no other nation in the world is peoplehood bound to its knowledge of the name of God (Igrot $\mathrm{Ha}$ Re'ayah, Vol. 1, Letter 20, p. 19-21)." In no other people is it true as in the Jewish people that religion "is the root element of its national life and a specific condition for the restoration of its country and the reshaping of its governing bodies" (ibid.).

Whereas the "national channel" of other nations is a medium, a framework in which the spiritual and cultural life of its members can subsist, the nationhood of Israel is neither a means nor an outer shape but in itself represents a spiritual content.

Naturally, the divine light is diffused throughout the whole world and its inhabitants but it is focused on the Jewish people. (Arfile Tohar, p. 70, 78)

The soul of the Jewish people is thus divine in a sense which contributes to its particular quality. Therefore the inner spirit of its nationhood is identical with its exterior frame:

The practical, national inclination of Knesset Israel, the Jewish people, is the outer garment of its spiritual inclination and the latter is the light and the soul of the former. Both emerge from the wellspring of the living God, and flow forth from the fountains of truth and divine faith. (Orot, Orot-Israel, ch. $6,158-161$ )

In the course of the redemptive process everybody will realise the necessity of perfecting religious belief with its two inseparabe components of national consciousness and observance of all halakhic precepts. ${ }^{16}$

\section{The Purpose}

If any other people had been subjected to the same conditions and historical circumstances it would have been assimilated into other nations. The reason the Jewish people continues to exist is the mission it received. The hand of God repeatedly interfered with its course on account of the ultimate, future purpose ordained for it.

In Kook's writing there is harmony between the national idea as he sees it, and the idea of Jewish mission. Rabbi Kook's teaching on vocation draws on those aspects of Jewish thought in which Torah and the divine precepts are directed towards a comprehensive, religious goal. The calling of Isreal is to realise this goal in actual history on behalf of all of humanity, as part of the drive towards inprovement that it shares with all of creation.

In keeping with prevailing scientific and philosophical tendencies Rabbi Kook had the courage to conceive of the realisation of the goal assigned to Israel as happening within the historical process of human reality. Thus, according to Kook, human history reveals a divine scheme of improvement and perfection of the species:

Perfecting the human race, preserving its quality and raising it, as preordained by Providence, into suitable rungs of holiness, improving all creation, leading it towards perfection. ("Te'udat Israel U-Le'umiyuto", p. $84)^{17}$

\section{Particularism and Universalism: The Two Messiahs}

Awareness of the essential universalism of this sacred task is, in Kook's thought, absolutely necessary if Jewish nationalism is not to degenerate into a form of national particularism liable to become an obstacle to final redemption:

If the idea of national revival was not as elevated as to contain a vision of eternity applying to all humanity we would not keep it in our hearts with such relish. (Igrot $\mathrm{Ha}$ Re'ayah, Vol. 2, 417) 
There exist righteous ones who are so powerful and mighty that they can not be enclosed in Keneset Israel but aspire towards the good of the entire world incessantly: these righteous ones can not possibly be national in the plain meaning of the word. (Orot $\mathrm{Ha}$ Kodesh, Vol. 3, ch. 32, 349)

To Kook, the universal aspect of Judaism is, from its very first stages, part and parcel of the Jewish process of redemption. In Jewish national redemption Kook saw the first step towards the elevation of mankind, the first step towards the increased spirituality which in Jewish tradition is attributed to the Messianic age. Kook describes the phases of redemption symbolically in terms of two types of Messiah, $\mathrm{Ma}$ shiah ben David, Messiah son of David, and Mashiah ben Joseph, Messiah son of Joseph. ${ }^{18}$ He does not describe their advent as an event, which is the prevailing notion in classical Judaism, but rather as a quality or a mark, an insignium. The two Messiahs are the symbols of an evolutionary historical process, not the intervention by a transcendent deity but the latter's immanent working in history according to preconceived intention. Evolution has been installed in the world from its creation. The details of the process, the time of specific events, depends on man.

In Messiah son of Joseph the particularly Jewish nationalism is revealed. But the final goal is not seclusion into national peculiarity but unification of all the world's creatures into one family in order for all to invoke the Name. And by the time the world moves from centering upon the national towards the common goal there will be a destruction of the things that took root during the phase of limited nationalism, the nationalism that is full of the ills of selfishness. This is the reason Messiah son of Joseph is predestined to be killed and that the genuine, lasting realm will be Messiah son of David.

And when people's longing for the common good waxes strong enough to effect the destruction of national peculiarity then evil itself will be eradicated from the life of the individual human being. Put in a different way, this means that the killing of Messiah son of Joseph is related to evil, to the destruction of the evil inclination [yezer ha-ra]. This is the reason why our sages disagreed on how to interpret the Book of Zachariah, Chapter 12: 10-11. In Zachariah it stands written,

'And I will pour upon the house of David, And upon the inhabitants of Jerusalem, The spirit of grace and of supplication;

And they shall look unto Me because they have thrust him through;

And they shall mourn for him, as one mourneth for his only son,

And shall be in bitterness for him, as one that is in bitterness for his first-born.

In that day shall there be a great mourning in Jerusalem,

As the mourning of Hadadrimmon in the valley of Megiddon.'

(Orot, Orot Israel, Ch. 6:6, 160). ${ }^{19}$

In the Babylonian Talmud (Sukkah 52a) these verses are treated divergently: "Rabbi Dosa and Rabanan were in disagreement. One said, 'They look to Me because they have thrust him through', that is Messiah son of Joseph, who was killed. And the other said, 'It is the evil inclination which was killed'." These allegations are further elaborated by them both, via the second part of the verse, "In that day shall there be a great mourning in Jerusalem. One sage said the mourning is for Messiah son of Joseph who was killed. The other said, 'For the evil inclination which will be cut down in the End of Days. And it is for the evil inclination that there will be a great mourning of all the people'."

Using the biblical text and its talmudic interpretations as base and starting point, Kook combines his conception of the two Messiahs into his particular, Messianic vision: Messiah son of Joseph as the physical-material aspect, symbolic of the rebirth of Jewish nationalism; and Messiah son of David as the sacred-spiritual aspect which will emerge after a period of national seclusion. In the words of the prophet Ezekiel (37:19): "... Thus saith the Lord God: Behold, I will take the stick of Joseph, which is in the hand of Ephraim, and the tribes of Israel his companions; and I will put them unto 
him together with the stick of Judah, and make them one stick, and they shall be one in My hand." In the stick of Judah, the house of David, spiritual and holy power are incarnated, and material strength and spiritual elevation will be unified. ${ }^{20}$

The Messianic vision is a continuation of the prophets' notion of the End of Days. Complete, universal redemption, the realisation of Messiah son of David, the ideal, is combined with the prophetic vision of shalom, the cosmic peace reigning at the End of Days. ${ }^{21}$ Shalom, peace, is generally identified with wholeness, perfection and Unity. In Kook's teaching the idea of unification is not only the one pertaining to Unity, i.e. the existence of a single, divine being which reveals itself as the One source of creation but also, equally, the divine energy which is intrinsic to all of creation, and constantly leading it towards future perfection and Unity.

As a mystic, Kook also used Kabbalistic concepts in shaping this idea. He describes in poetic and colourful terms how the world's final tikkun, healing, restitution, will occur when generality, represented by Hokhmah (wisdom), the second sfirah (emanation), of the Tree of Life, is united with individuality, represented by Binah (understanding), the third sfirah (Orot Ha-Kodesh, Vol. 1, ch. 52, 57):

Binah represents the ideal world in its complete goodness, delight and bliss, not as it is now with its distress and its pettiness but a world of fullness, a superior world with $a b-$ solute freedom from every oppression. And from Binah, in direct connection with the world of the Divine, streams the power of Hokhmah, more supreme than any attainable power of discernment, the complete future ideal. Messianic redemption will mean the union of Hokhmah and Binah. ${ }^{22}$

\section{Communal Existence}

In Rabbi Kook's world view national essence is prior to the essence of the individual in that it creates and crystallizes the individual as be- longing to a specific collective reality. The national essence is the chain binding the individual to her or his fellow man, and thus to the cosmos:

The ethical element of nationalism is nothing but the gratitude of the individual towards the community for the benefit received from it, materially as well as culturally. But the root of that gratitude is the gratitude towards the Lord of all Works ... It is the wish of God to further the development of mankind through the completion of our fellowship. ("Te'udat Israel Ule'umiyuto", p. 227)

The single individual cannot be considered a goal unto herself. A separate realisation of one's individual essence has no meaning, contains contradiction, and produces antagonism:

All the world's ills, both material and spiritual ones, stem from the fact that each individual sees only one aspect of existence, namely the one that is pleasing to him. And that all other aspects which are incomprehensible to him only deserve to be eradicated from the world. What follows is increased strife and intensified conflict. (Orot Ha-Kodesh, Vol. 1, ch. 107, 120-121).

Kook makes a distinction between two aspects of Jewish peoplehood here: "the national idea" which was prominent during the time of the First Temple, and its substitute in the Second Temple period, "the religious idea". The "religious idea" focuses on "the single person, on personal, individual ethics, the concern with personal, individual, eternal life..." (Orot,"LeMahalakh Ha-Ide'ot", ch. 5, 110), and is a degenerate version of the "divine idea" which can only be made manifest in a community (Orot, "Le-Mahalakh Ha-Ide'ot", ch. 2, 104-105).

Rabbi Kook views communal existence, "the creation of a collective personality", the nation, as a central component of Jewish existence,

A great people does not exert its influence through a part of itself but through its complete being. A being in freedom. As long 
as the striving for divine ideals and their realisation in a continual historical existence cannot be made fully manifest the shekhi$n a h$, Presence, is in exile and the life potency produced in serving God is impaired. (Ikve Ha-Zon, p. 138)

Freedom is found neither inside the individual person nor in social complexity. Here we must understand freedom as "the ideal community" among other communities; as a fundamental value attached to one people as a family among the nations.

\section{The State}

In classical Jewish tradition no middle phase between exile and Messianic redemption is predicted. Halakhically observant Jews felt that the idea of an independent Jewish state, if not brought about by Providence, was an illegitimate heir to Jewish history. The state they prayed for was a Messianic one, a holy commonwealth based on halakhah. Rabbi Kook's identification of Zionist reality with the process of religious redemption made innovative thinking on the state and its position in the process of redemption necessary.

Rabbi Kook advanced the argument that a full national life is impossible unless the people in question is in possession of its own country complete with social and political institutions able to provide full expression of its national spirit,

It is necessary for this community to possess a political and social state. That it becomes 'a wise and understanding peoplethis great nation' [an echo of Deuteronomy 4:6] in which the absolute, divine idea is prominent, the idea which will quench, reenliven, and permeate the people and the land by its light (Orot, "Le-Mahalakh HaIde'ot", ch. 2, 104). ... And through its return to Zion the Jewish people will again, as a people among other peoples, be able to carry the torch of holiness in all its purity among the peoples of the world. (Hazon

\section{Ha-Geullah, p. 178)}

The Jewish state is no goal in itself, nor acceptable by itself but represents the spirit of Judaism, and will come to exist in order that the particular qualities of the people may be fully revealed in the light of prophetic guidance:

That the state is not the greatest happiness for man can be said about a normal state whose merit does not exceed that of a society of mutual responsibility. But that is not true of a state upon whose existence the noblest ideas are inscribed. Such a state is truly the greatest happiness and such a stete is our state of Israel, whose wish is that God shall be one and his name one, which is truly the greatest happiness. (Orot, "Orot Israel", ch. $6: 7,160$ )

Only independent statehood will make it possible to sanctify national life by organising it in accordance with the Torah of Israel. Only then will it be possible for Judaism to testify to the world

both a political Torah advancing peace and freedom, and a religious Torah enlightened by the knowledge of divine truth and love of the paths of God within the single person and in life with people. (Hazon Ha-Geullah, p. 202).

The Heretics, Heresy, and the Religious Redemption of Israel

Rabbi Kook's self-imposed task of making national-Zionist activity legal was more difficult than that of his predecessors. It was obvious that neither the cultural nor the educational endeavours of the Zionist movement were in line with traditional outlooks, and that the larger part of the movement's adherents, pioneers as well as ideological leaders, did not observe the mizvot, precepts of Torah; instead, they harboured socialist theories and attempted to crystallize a new Jewish national identity 
divorced from the values and practices of the religious tradition. The greater part of Orthodox Jewry, on their part, were among the bitter enemies of Zionism. ${ }^{23}$

The pioneers' negative attitude toward religion on the one hand and their laudable work and self-sacrifice on the other put Kook in a serious dilemma: what was he to think concerning these young people who were causing him, simultaneously, feelings of admiration and reservation, love and disappointment? He recognised a strong spiritual tension between his own adherence to the Law, the obligation of every Jewish person, and his profound understanding of the heresies of his time:

It is difficult, very difficult, to love a Jew who contemptually transgresses the Laws of our holy Torah... The pain is piercing and cannot be healed. ("Te'udat Israel Ule'umiyuto", p. 64-65)

And yet,

to pray with the transgressors, I say, and not take into consideration their delinquent opinions. (Igrot Ha-Re'ayah, Vol. 2, p. 17172)

Nothing was more alien to Kook than compliance and compromise as regards faith and observance of the commandments. He saw belief as a state of complete security and trust. Without belief and attachment to God it was impossible for man to live a natural life. And therefore there was no other way for him than painful confrontation between believers and anti-religious Jews. But one must, as Kook saw it, approach this confrontation with deep love, and with the awareness that Jews who sin are also amomg the children of God:

But what [the secularists] want is unknown to themselves; to such a degree is the spirit of Israel associated with the spirit of God that even in the case of someone who avers that he is not in need of the spirit of God, the divine spirit dwells in the kernel of his endeavor against his will since de does maintain that he is attached to the spirit of Israel ... (Orot, "Orot Ha-Thiyah", ch. 9, p. 6364)
Within a comprehensive, religio-philosophical frame Kook tried to diminish the contradiction between religious heresy on the one hand, and on the other the national and social idealism which led to achievements that were in fact part of his own Messianic aspiration. This contradiction could not be explained away in ordinarily nomistic, conventional terms. At the same time, Kook was of the opinion that Orthodox Judaism lacked the constructive energy of the secular world, and had not reached the latter's stage of creativity. Therefore, Orthodox Jewry was without influence and had no shaping and creative power in Palestinian life and society.

Rabbi Kook's firm desire to adapt secular achievement for the benefit of faith was often apparent in his readiness to judge various phenomena in ways that went beyond purely halakhic estimation, or to push to their limits those schools of Jewish thought which would renounce on the exclusion of these everyday phenomena from religious life. Kook abided by the paradoxical saying of the Sages on "the insolence which will grow in the footsteps of the Messiah (ikvata de-meshiha)" (Sotah 49b) in order to explain the transgressions of secularists and heretics, their desecration of the Shabbat, and their eating of hamez (fermented dough) and other forbidden foods:

The insolence of ikvata de-meshiha is the diminution of light that takes place before the re-formation of the vessels [tikkun] and bears no resemblance to other types of delinquency... (Orot, "Orot Ha-Thiyah", ch. 39, p. 82-83)

In ikvata de-meshiha everybody who, by the inclination of his heart, is dedicated to the deliverance of Israel has a soul of supreme righteousness which cannot be assessed by ordinary measure. (Arfile Tohar, p. 29)

The world must, according to Kook, not be judged by its present state but by the reality ordained for its future. In order to characterize the young pioneers without faith he established an additional type of Jewish person, neither Orthodox and god-fearing nor infidels and sinners of Israel, but the Insolents or, put in a 
more colourful way, Souls of Chaos, whose existence testifies to the closeness of the days of the Messiah:

The idealism of the Souls of Chaos or the Insolents originates from a point of holiness. (Orot, "Zer'onim", ch. 3, p. 122)

Occasionally one finds a heretic in whom a potent, inner, glowing faith flows forth from the source of supreme holiness, a faith stronger than that of thousands of Observants of little faith. (Orot Ha-Emunah, p. 21)

The Insolents or Souls of Chaos cannot come to terms with a world of injustice and evil but strive to build another world, a world of justice in which perfection and wholeness can exist. Rabbi Kook placed the Insolents on a higher spiritual level than the Orthodox. He maintains that their souls are rooted in a higher level (of the Tree of Life) than the souls of the Orthodox,

The souls of the Insolents of ikvata de-meshi$h a$, those who bind themselves in love to the concerns of all of Israel, are more repaired than those of the Orthodox who, since they are not working for the good of the whole community of Israel and the restitution of the nation and the land, are devoid of this asset. (Orot, "Orot Ha-Thiyah", ch. 43, 84)

Rabbi Kook even said that the acts of the Insolents in rebuilding Erez Israel, and their heresy, are necessary, desired by the Creator, and likely to further redemption:

The heresy will cleanse away the dross accumalated on the lower levels of religious faith so that faith of a higher order may emerge, purified. (Orot, "Orot Ha-Thiyah", ch. 51,87 )

In spite of the heavy conflict in which he found himself, Kook was determined to continue to work among the pioneers, whom he saw as unintentionally righteous. He belived that it was in his power to kindle in them the divine spark, the "light and the holiness hidden at the bottom of every soul in Israel" (Igrot Ha-Re'ayah,
Vol. 1, 242). He was convinced that all who return to Zion in the depth of their souls wish to return to God, to be reintegrated with God (tshuvah) even though this inclination is still latent, unconscious to them.

The possibility of kindling tshuvah (return) is within Israel. This tshuvah, turning, is an inner tshuvah, concealed by many obstructing veils, but no obstacle or hindrance possesses the power to prevent the supreme light from shedding its splendour upon us. (Orot Ha-Tshuvah, p. 122-23) ${ }^{24}$

Secularity is no more than an obstructing veil and the pioneers are not rebels who throw off all restraint but in their hearts potential repentants, although ignorant ones.

Rabbi Kook believed that all of Israel, qua Israel, had a hidden attachment to the holy Torah:

The righteous ones, the Everlasting Foundation [of Israel] treat everyone with kindness and defend all transgressors, even the heretics and the greatest, most hardened sinners because they [the righteous] in their integrity see the spark of goodness hidden in every soul and all the more in the souls of Israel, mainly in the souls that stand up for the love of the nation and aspire toward goodness and righteousness. (Orot $\mathrm{Ha}-\mathrm{Ko}$ desh, Vol. 3, ch. 25, 340)

\section{Sacred and Profane, Spirit and Matter}

The essential conflict between Kook's view and those that prevailed among the extremely Orthodox were centred on the issue of sacred versus profane. The Orthodox extremists saw the two concepts as opposites. They saw separation from the profane and attachment to holiness as ideal whereas Kook describes the relation between the two as a dialectic one. ${ }^{25}$ To the Orthodox, religious transgression equals social transgression, unethical conduct, injustice and disorderly behaviour. Rabbi Kook, in contrast, said, 
We do not regret it if some aspect of social justice can be established without reference to God since we know that the striving for justice itself is an expression of the most splendidly divine influence. (Igrot $\mathrm{Ha}$ Re'ayah, Vol. 1, 45)

Rabbi Kook saw in the universe an immanent holiness so strong that even someone who is not aware of this holiness will eventually return to the wellspring of salvation:

It is well-established rule that even though the world appears to be steadily descending this is only true when nothing but its exterior is seen. In terms of its inner powers, every generation adds something to the previous ones in that holiness is added, congeals, and grows. Holiness rests in reality with all its shades and nuances. The profane is but a veil hiding the sacred light. (Igrot Ha-Re'ayah, Vol. 1, 369)

Rabbi Kook felt that sacrality is perceptible in every phenomenon intended to improve on material life and civilisation:

[only because of narrowmindedness, envy, and jealousy do] people oppose science, heroic deeds, grandeur and progress and declare them unsuitable using the argument that these phenomena are outside the world's religious content. In religious perception, the Divine is seen as appearing in every worldly reform whether individual or public, spiritual or material. It only judges in terms of the use or the harm of these things and so, no movement can be entirely guilty while in the process of creating something new, either materially or spiritually (Arfile Tohar, p. 47) ${ }^{26}$

Rabbi Kook was of the opinion that the Jewish people had become too spiritual, too remote from the world. In this thought, the exile becomes a period of striving for spirituality beyond reason, at the cost of natural elements. In fulfilment of materiality he saw one of the conditions for the purification of the spirit. The stability of holiness depends on the solidity of physical nature, the goal being to re-establish harmony between holiness and its vessels. Kook had positive feelings about physical training, for example, an attitude directly and pointedly opposed to the Orthodox Jewish one:

Great is our physical need, we need a healthy body. We have been heavily engaged in spirituality. We forget the holiness of the body; we have abandoned health and physical strength. Our tshuvah will not come to be until it, in all its spiritual splendour, will also be a material tshuvah creating healthy blood, firm and well-formed bodies, strong muscles. (Orot, "Orot Ha-Tḥiyah", ch. 33, 80)

Holiness is the goal and the measure. But without the profane it cannot exist:

The sacred must be built upon the foundations of the profane. The profane is the substance of the sacred, and the sacred the form. And the stronger the substance, the more important becomes the form. (Orot Ha-Kodesh, Vol. 1, ch. 127, 145)

Holiness needs a foundation on which to be established, so to speak. Even in the state of supreme holiness in which species and planet merge before the face of God is man obliged to live a full life for the sake of holiness:

Everyday life will not be annulled, ordinary human transactions, physical life, the lives of individuals and communal life will not be blurred, but will rise toward the ideal level, toward supreme holiness. (Orot Ha-Kodesh, Vol. 2, ch. 9-12, 299-302)

Rabbi Kook's feeling of Messianic tension, his visionary qualities led him, in view of paradoxical, contemporary realities, towards a religious solution in which the notion of holiness was stretched to its limits, and spiritual significance assigned to the inspirited, real world. Thus he was able meaningfully to interpret as an act of God the fact that the sacred mission of redemption was placed in the hands of heretics, and to grant an importance akin to holiness, 
indeed to make holy, the Zionist movement in spite of its predominantly secular nature.

Observation of the world as it is, the whole universe, is likely to reveal the true essence of it, its unity. The aim of religious contemplation is not to split the world into fragments, and in it to assign a domain to faith. It is here to see the world in its given multitude. ${ }^{27}$

The righteous do not grieve over sinfulness But add justice.

They do not grieve over heresy

But add faith.

They do not grieve over ignorance

But add wisdom. (from Arfile Tohar, p. 28)

\section{NOTES}

* The work on this article was supported by the Danish Research Council for the Humanities; translated by Ellen M. Pedersen.

1. Cf. Mishneh Torah, Hilkhot Melakhim, 11:4.

2. Cf. Sanhedrin 110, and Midrash Tanhuma on Deuteronomium 4.

3. See Jacob Katz, "Messianism and Nationalism In Ha-Raw Juda Alkalai's Teaching" (in Hebrew), in his Jewish Nationalism, Jerusalem 1976, 308-356.

4. See Jacob Katz, "The Historical Figure of Ha-Rav Zvi Hirsch Kalisher" (in Hebrew), ibid., p. 285-307.

5. See further, Judah Alkalai, Collected Writings (in Hebrew), Jerusalem 1975, Mainly "Minhat Yehudah" from 1843; and Zvi Hirsch Kalisher, Drishat Zion, Jerusalem 1965 (1862).

6. On both organisations, see Yeshayahu Wolfsberg, Ha-Mizrahi and Ha-Po'el Ha-Mizrahi (in Hebrew), Jerusalem 1964; Aryeh Fishman, "Tradition and Innovation", In Avraham Rubinstein (ed.), In The Paths of Renewal: Studies in Religious Zionism (in Hebrew), Ramat Gan 1983, 127-147. Mizrahi, the religious Zionist movement, was formed in 1904.

7. See also Harold Fisch, The Zionist Revolution, London 1978; Yehudah Maimon, Religious Zionism and Its Development (in Hebrew), Jerusalem 1933; Yiẓhak Reines, New Light Over Zion (in Hebrew), Warsaw 1902.

8. See Jacob Katz, "Israel and the Messiah". Commentary, Vol. 73, No. 1. New York 1984, 34-41.
9. "Channel", zinnor, is a favourite term among sages influenced by Kabbalistic thought. Orig. designation: the channels that form the connections between the emanations of the Tree of Life.

10. In Ben Zion Bokser, "Jews, Arabs and Japanese: Letters by Rabbi Abraham Isaac Kook". Judaism Vol. 32, No. 2. New York 1983, 184-87.

11. On Degel Yerushalayim, see entry in Raphael Patai (ed.), Encyclopedia of Zionism and Israel, Vol. 1. New York 1971, 246. The manifesto is found in full length in Rabbi Kook's Orot, p. 185-86.

12. Diverging conceptions are found in Tamar Ross, 1982 (see Bibl. II); and in Nathan Rothenstreich, Jewish Philosophy In Modern Times (in Hebrew). Vol. 2, Tel Aviv 1966, 257ff. English transl. New York 1968.

13. For an overview, see Jacob S. Levinger, From Routine to Renewal: Pointers in Contemporary Jewish Thought (in Hebrew), Jerusalem 1973, 46-56.

14. Quoted from Friedman, 1977, p. 107 (see Bibl. II). 15. Cf. Mordecai Eliasberg, The Path of Gold (in Hebrew). Warsaw 1897, 28-30, and 43.

16. Several different aspects are added in Abraham J. Heschel, An Echo of Eternity, New York 1969; André Neher, L'Existence Juive, Paris 1962.

17. On Purpose, se further, Eliezer Goldman, "Secular Zionism, the Vocation of Israel, and the Telos of the Torah" (in Hebrew). Daat; A Jornal of Jewish Philosophy and Kabbalah, No. 11. Ramat-Gan 1983, 103-126.

18. On Redemption, and on the two Messiahs and their reciprocal relation, see Gershom Scholem, The Messianic Idea in Judaism. London 1971.

19. On the translation: For this, and for the following biblical passage we have used Soncino Books of the Bible, ed. A. Cohen, London 1948-50; text by The Jewish Publication Society of America.

20. See also Zvi Yaron, 1979/1983, p. 282ff (Bibl. II). 21. On the term of shalom in a wide historical and philosophical context, se Aviezer Ravitzky, "The Term of Shalom in Jewish Thought" (in Hebrew). Daat; A Journal of Jewish Philosophy and Kabbalah, No. 117, Ramat Gan 1986, 5-22.

22. See Tamar Ross, 1982, for a thorough discussion of cosmic tikkun (Bibl. II).

23. See further Yosi Avneri, 1983, and Eliezer Schweid, 1981 (Bibl. II).

24. Orot $H a-T s h u v a h$ exists in English translation, see Bibl. I. On individual versus cosmic tshuvah, see Lawrence Englander, 1985 ( $\mathrm{Bibl}$. II).

25. Cf. Zvi Yaron, 1979, p. 107-12 (see Bibl. II). 
26. Quoted in Tamar Ross, 1982, Part II, p. 54.

27. See also Nathan Rothenstreich, p. 253.

\section{BIBLIOGRAPHY}

\section{Works by Rabbi Kook}

Arfile Tohar (Clouds of Purity). 80 pages published 1914. Several sections were later incorporated into other books by Rabbi Kook Hazon Ha-Geullah (The Vision of Redemption) Jerusalem 1949.

Igrot Ha-Re'ayah (The Letters of Rabbi Avraham HaCohen Kook). Jerusalem. Vol. 1-2, 1961; Vol. 3, 1965; Vols 1,2: 2nd ed.

Eder Ha-Yaker and Ikve Ha-Zon (The Precious Mantle). Jerusalem 1967.

Orot Ha-Kodesh (The Lights of Holiness). Jerusalem Vol. 1, 1963; Vol. 2-3, 1964. All 2nd eds.

Orot Ha-Re'ayah (The Lights of Rabbi Avraham Yizhak HaCohen Kook). Jerusalem 1970. Orot Ha-Tshuvah (The Lights of Penitence). Jerusalem 1966. English transl. by B.Z. Metzger, Rabbi Kook's Philosophy of Repentance: A Translation of Orot Ha-Teshuvah. New York 1968.

$T e^{c}$ udat Israel Ule'umiyuto (The Mission of Israel and Its Nationhood). Ha-Peles 1901. Repr. in Azkarah, Jerusalem 1937-38.

Orot (Lights). Jerusalem 1961. This ed. contains several essays, of which are quoted here: "Le-Mahalakh Ha-Ide'ot Be-Israel" (On the Development of Ideas in Israel); "Orot Israel" (The Lights of Israel); "Orot Ha-Thiyah" (The Lights of Renewal); "Zer'onim" (Seeds).

II. Works (largely) devoted to studies in Kook's thought
Agus, Jacob B, 1946, High Priest of Rebirth: The Life, Times and Thought of Abraham Isaac Kook. 2nd ed. 1972. New York.

Avineri, Shlomo, 1980, "Ha-Rav Kook: The Dialectics of Redemption"; in his: Varieties of Zionist Thought (in Hebrew), Tel Aviv: 216226; English transl., New York 1981.

Avneri, Yosi, 1943, "Ha-Rav Avraham Yizhak Ha-Kohen Kook and his Contacts With the People of the Second Aliyah in the Years 19041914"; in Avraham Rubinstein (ed.), In the Paths of Renewal: Studies in Religious Zionism (in Hebrew). Ramat-Gan, 9-80.

Bokser, Ben Zion, 1978, Abraham Isaac Kook: Translation and Introduction. New York.

Englander, Lawrence A., 1985, "Rav Kook's Doctrine of Teshuvah". Judaism Vol. 34, No. 2. New York.

Epstein, Isidore, 1951, Avraham Yitzhak Hacohen Kook: His Life and Works. London.

Friedman, Menachem, 1977, "Rabbi KookBetween Tradition and Innovation"; in his: Society and Religion. The Non-Zionist Orthodoxy in Erez-Israel 1918-1936. (In Hebrew). Jerusalem: 87-109.

Ross, Tamar, 1982, "Rav Kook's Concept of God". (In Hebrew). Daat; A Journal of Jewish Philosophy and Kabbalah. Part I, No. 8: 109128; part II, No. 9: 39-70. Ramat-Gan.

Schweid, Eliezer, 1979, "A Land of Promise Which is a Homeland: Erez Israel in Avraham Yizhak Ha-Kohen Kook's Teaching"; in his: Homeland And a Land of Promise (in Hebrew). Tel Aviv, 186-203.

Schweid, Eliezer, 1981, "Secularity From the Religious Point of View: Rabbi Kook's Teachings"; in his: Judaism and Secular Culture (in Hebrew). Tel Aviv, 110-142.

Yaron, Zvi, 1979, The Philosophy of Rabbi Kook (in Hebrew). Jerusalem.

Yaron, Zvi, 1983, "Tolerance in the Teachings of Ha-Rav Avraham Yizhak Ha-Kohen Kook". In Mosheh Ishon (ed.). The Unity of the $\mathrm{Na}$ tion (in Hebrew). Jerusalem, 209-255.

Zoref, Efraim, 1961, The Life of Ha-Rav Kook (in Hebrew). 3rd ed., Jerusalem, Tel Aviv. 